Current Gene Therapy

Review

\title{
Gene therapy for gastric diseases
}

Shintaro Fumoto, Junya Nishi, Junzo Nakamura ${ }^{*}$ and Koyo Nishida

Graduate School of Biomedical Sciences, Nagasaki University, Japan

*Address correspondence to this author at the Graduate School of Biomedical Sciences, Nagasaki

University, 1-14 Bunkyo-machi, Nagasaki 852-8521, Japan; Tel: +81-95-819-2453; Fax:

+81-95-819-2897; E-mail: junzo@nagasaki-u.ac.jp 
Abstract: Gene therapy for gastric cancer and gastric ulcer is a rationalized strategy since various genes correlate with these diseases. Since gene expressions in non-target tissues/cells cause side effects, a selective gene delivery system targeted to the stomach and/or cancer must be developed. The route of vector transfer (direct injection, systemic, intraperitoneal, gastric serosal surface and oral administration) is an important issue which can determine efficacy and safety. Strategies for cancer gene therapy can be categorized as suicide gene therapy, growth inhibition and apoptosis induction, immunotherapy, anti-angiogenesis, and others. Combination of the target gene with other genes and/or strategies such as chemotherapy and virotherapy is promising. Candidates for treatment of gastric ulcer are vascular endothelial growth factor, angiopoietin-1, serum response factor, and cationic host defense peptide cathelicidin. In this review, we discuss stomach- and cancer-targeted gene transfer methods and summarize gene therapy trials for gastric cancer and gastric ulcer.

Keywords: Gastric cancer, carcinoma, gastric ulcer, gene delivery, stomach 


\section{INTRODUCTION}

The stomach is a digestive organ that is essential for nutrient intake. An acidic environment in the stomach is required for the digestive system and a barrier function against acidic $\mathrm{pH}$ is necessary. Alcohol, drugs, stress, and Helicobacter pylori (H. pylori) reduce barrier function and cause gastritis and gastric ulcer. Moreover, gastric cancer is one of the most common malignant tumors in the world. It was the second most common cause of death from cancer (700,000 deaths annually) after lung cancer in 2002, according to the International Agency for Research on Cancer [1]. In 2002, the incidence of gastric cancer was estimated to be 934,000 new cases per year worldwide [1]. The mortality due to Japanese gastric cancer was over 50,000 deaths annually in 2005 according to the Center for Cancer Control and Information Services, National Cancer Center, Japan. Surgical resection of gastric cancer without metastasis is a first-line therapy and provides relatively good prognosis compared to other cancers. However, recurrence, liver metastasis and/or peritoneal dissemination in gastric cancer are serious problems with high mortality. Advanced gastric cancer does not generally respond to conventional chemotherapy or radiotherapy [2].

To treat gastric cancer and gastric ulcer, gene therapy is a promising approach because mutation, overexpression and insufficient expression of various genes correlate with these diseases. Gene delivery systems in vivo can be categorized as viral [3-5] and non-viral [6-8] approaches. Although the viral vectors have not yet proved to be a safe gene delivery method [9, 10], the transfection efficiency of viral vectors is generally much higher than that of non-viral vectors. Not only transgene expression, but also down-regulation of internal genes, is possible 
using antisense oligodeoxyribonucleotides [11] and siRNA [12, 13]. Selection of administration routes for gene therapy is an important issue, along with vector and target gene selection. In this review, we discuss stomach-targeted gene transfer methods and summarize gene therapy trials for gastric cancer and gastric ulcer.

\section{SELECTIVE DELIVERY OF GENES TO THE STOMACH OR GASTRIC CANCER}

Since it is thought that gene transfer to non-target organs/cells can result in severe adverse effects, selective gene transfer to target organ/cells, i.e. the stomach or cancer, is a major challenge in gene therapy, and a gene delivery system targeted to the stomach or cancer should be developed. The administration route is an important factor since it can greatly affect biodistribution of vectors. Active targeting to cancer cells has also been tried by several groups. More than half of advanced gastric cancers overexpress the carcinoembryonic antigen (CEA) protein $[2,14]$. CEA is an attractive target since its expression in normal cells is generally low. Khare et al. developed a murine leukemia virus-based recombinant retroviral vector that displays a chimeric envelope protein containing a single-chain variable fragmented antibody to CEA [15]. Normally, wild-type ecotropic viruses do not infect human cells. In contrast, this vector infected human CEA-expressing cells. Tanaka et al. constructed a genetically modified adenovirus incorporating an IgG Fc-binding motif from the Staphylococcus protein A, Z33, within the HI loop (Adv-FZ33) [16]. Combination of Adv-FZ33 with an anti-CEA monoclonal antibody resulted in 20 times higher LacZ or EGFP gene expression than that with a control antibody in MKN-45 gastric cancer cell line. Notably, this system is easily applicable to other antibodies. 
Epithelial cell adhesion molecule (EpCAM) is another target for tumor-selective gene transfer. Heideman et al. reported that EpCAM-targeted adenoviral vector using bispecific antibodies against the adenovirus fiber-knob protein and EpCAM selectively infected gastric and esophageal cancer cell lines [17].

On the other hand, a cancer-specific promoter is another tool achieving cancer-specific gene expression. A CEA promoter is commonly used for this purpose [18-20]. However, the gene expression level of tumor-specific promoters such as CEA promoter is generally low. To resolve this problem, Ueda et al. designed a Cre/loxP system under the control of a CEA promoter, and gene expression (under the control of a strong promoter) was markedly enhanced while maintaining specificity using the Cre/loxP regulation system [21]. Cyclooxygenase-2 (COX-2) promoter is also an attractive promoter since its activity is high in gastrointestinal cancer (or inflammation site) while its activity in most tissues such as the liver is low [22-24]. Yamamoto et al. demonstrated that COX-2 promoter was less active than cytomegarovirus (CMV) promoter in the liver, lung and kidney after tail vein injection of adenoviral vector, whereas activity of COX-2 promoter in subcutaneous tumors of gastric cancer cells after intratumoral injection was similar level with that of CMV promoter [25].

\section{ROUTES OF VECTOR TRANSFER}

Routes of vector transfer into the stomach (summarized in Fig. (1) and Table 1) can theoretically determine the efficacy and safety of vectors. When foreign genes are administered via the vasculature route, they are distributed to the whole body through the bloodstream, leading 
to inadequate stomach-selective or disease site-selective gene delivery. Injection of vectors into the gastric artery may resolve this problem; however, there are no reports about stomach-selective gene transfer via the gastric artery. As for tumors, there are considerable numbers of reports about cancer-targeted delivery systems via the vasculature route. One such system is the PEGylated carrier system [26]. PEGylated carriers accumulate in the tumor via an enhanced permeability and retention (EPR) effect [27]. Active targeting systems utilizing tumor-specific surface receptors have also been developed [28-30]. However, no researchers have achieved stomach- or gastric cancer-selective gene transfer via the systemic circulation. Thus, it may be necessary to select other routes for stomach-targeted gene therapy.

\section{Direct injection to the stomach}

When plasmid DNA is injected directly into muscle, efficient transfection activity can be obtained without any carriers [31]. This method has been applied to the liver [32], heart [33], spleen [34], tumor [35], and also to the stomach [36]. However, multiple injections are necessary for gene transfer to a large population of gastric cells. Moreover, there is great concern about safety because this method requires physical force against the organs; consequently, repeated administration of plasmid DNA is limited, except for solid tumors.

\section{Serosal route}

The prognosis of gastric cancer patients with serosal invasion is poor [37]. The survival rate is also influenced by peritoneal dissemination [38]. Therefore, the serosal route of gene 
transfer is attractive to treat serosal invasion and peritoneal dissemination of gastric cancer. Intraperitoneal injection has been widely applied as a gene transfer route $[20,39,40]$. Since intraperitoneal injection of vectors can result in non-specific gene transfer into non-target sites/cells in the peritoneal cavity, an active targeting system and/or cancer-specific promoter is required for safety.

The stomach-selective gene transfection method is expected to be a safe and effective treatment against gastric cancer localized in the stomach. We have developed an organ-selective gene transfer method, instilling naked plasmid DNA onto the mesothelial surface of target organs including the liver [41], unilateral kidney [42], spleen [43], unilateral lung [44], and stomach [45, 46] in mice. Although frequent dosing using this method is limited due to necessity of laparoscopy, application of an implantable infusion pump will prolong duration of gene expression. Gastric serosal surface instillation of plasmid DNA encoding an anti-cancer gene is thought to act primarily against the invasion of gastric cancer to the serosal side, although it may be difficult for plasmid DNA to penetrate into the mucosal side. However, prophylactic gastric serosal instillation of plasmid DNA combined with the resection of mucosal cancer might be useful to prevent invasion of the remaining cancer cells. Furthermore, we previously reported that gastric serosal surface application of the anti-cancer drug 5-fluorouracil (5-FU) resulted in comparable distribution of 5-FU between the mucosal and serosal sides in rats; consequently, 5-FU was efficiently distributed to the mucosal side from the serosal side prior to distribution to the systemic circulation [47]. Simultaneous administration of gene medicine and anti-cancer drugs onto the gastric serosal surface may thus be a promising strategy against gastric cancer. 


\section{Oral route}

The oral route is the most attractive and challenging route. Non-invasive administration is possible by the oral route. Potential daily intake is also one of the merits of oral administration of vectors. Moreover, since gastric cancer and gastric ulcer are firstly generated on the mucosal side of the stomach, vectors can act against these diseases effectively. However, the epithelial barrier, low $\mathrm{pH}$ and digestive fluid are major obstacles for gene transfer. Shao et al. reported that the in vivo stability of a recombinant adeno-associated virus type 2 vector could be improved by gastric acid neutralization with sodium bicarbonate and protease inhibition with aprotinin [48]. Despite these changes, transduction after oral administration of this vector remained low. (Shao et al. did not find $\beta$-galactosidase-positive cells in any of the mice.) We also failed to detect transgene expression after intragastric injection of plasmid DNA in mice [46]. To overcome these obstacles, microparticles and nanoparticles are a promising approach. Chitosan-DNA microparticles could protect the encapsulated plasmid DNA from nuclease degradation [49]. In in vivo-animal studies, a blue color was observed with X-gal staining of histological stomach and small intestine sections after oral administration of chitosan-DNA microparticles. More recently, Zheng et al. reported that chitosan nanoparticles using quaternized chitosan $(60 \%$ trimethylated chitosan) which were given via a gastric feeding tube exhibited green fluorescent protein expression in the mucosa of the stomach, duodenum, jejunum, ileum, and large intestine [50]. Furthermore, Bhavsar and Amiji developed a hybrid system dubbed the nanoparticles-in-microsphere oral system (NiMOS) which consists of gelatin nanoparticles 
(containing plasmid DNA) and a poly(epsilon-caprolactone) outer shell [51]. NiMOS resided in the stomach and small intestine for relatively longer than gelatin nanoparticles alone. Future application of these systems to viral vectors may improve transduction efficiency. It may be difficult for an oral delivery system alone to achieve stomach-selective gene transfer; therefore, combination with an active targeting system and/or cancer-specific promoter will be required.

Gene transfer via these routes may result in gene expression in a limited region, i.e., administration site (mucosal or serosal sides for the oral or serosal route, or the submucosal and muscular layers for direct injection). Combination of these routes can theoretically resolve this problem.

\section{APPROACHES TO TREAT GASTRIC CANCER}

Several approaches to treat gastric cancer have been reported. These can be categorized as suicide gene therapy, growth inhibition and apoptosis induction, immunotherapy, anti-angiogenesis, and others (Table 2). Since the efficacy of single gene transfer is generally low, combination of several strategies should be considered.

\section{Suicide gene therapy}

The narrow therapeutic range of anti-cancer drugs is major problem of chemotherapy; frequently, effective and toxic doses are inverted. To improve the efficacy of anti-cancer drugs, suicide gene therapy is a promising approach [52]. Suicide gene therapy is defined as a combination of a suicide gene with a less-toxic prodrug, such as herpes simplex virus thymidine 
kinase (HSVtk) with ganciclovir (GCV) and Escherichia coli cytosine deaminase (CD) with 5-fluorocytosine (5-FC). If a suicide gene is selectively transferred to the tumor cells, the systemically administered prodrug can be converted to its active form in tumor cells. Moreover, suicide gene therapy is effective even with small populations of suicide gene-positive cells because the active form of the prodrug can spread from a suicide gene-positive cell to neighboring cells via gap junctions. This effect is known as the "bystander effect", which was originally described as a phenomenon that HSVtk-positive cells sensitive to GCV were toxic to nearby tumor cells resistant to GCV. [53]. Tanaka et al. tested a recombinant adenovirus vector carrying the HSVtk gene coupled to the CEA promoter for human gastric carcinoma cells in vitro [18]. The $50 \%$ growth inhibitory concentrations $\left(\mathrm{IC}_{50}\right)$ of $\mathrm{GCV}$ were 21 and $5.8 \mu \mathrm{M}$ for CEA-producing gastric carcinoma cell lines $\mathrm{MKN} 28$ and $\mathrm{MKN} 45$, while $\mathrm{IC}_{50}$ in a CEA-non-producing cancer cell line MKN1 was $320 \mu \mathrm{M}$. This system, i.e. a suicide gene under the control of a cancer-specific promoter, is also effective in vivo. Tanaka et al. continuously tested the in vivo effect of the same system, and intratumoral injection of the vector with intraperitoneal injection of GCV inhibited the growth of subcutaneous tumor xenografts of gastric cancer by $20 \%$ compared to untreated tumors [19]. Lan et al. reported that intraperitoneal injection of an adenovirus carrying the CD gene under the control of a CEA promoter with 5-FC suppressed tumor growth and prolonged survival of mice in MKN45 tumor xenograft model, suggesting this system is also effective against peritoneal dissemination [20]. In contrast, significant hepatic toxicity was noted in animals treated with an adenovirus carrying the CD gene under the control of a non-specific strong promoter (CAG promoter), suggesting that selective 
gene transfer is an important issue.

\section{Growth inhibition and apoptosis induction}

Since abnormal gene expression and/or mutation of various oncogenes and tumor-suppressor genes correlate to proliferation and survival of tumor cells, gene therapy is rational. Suppression of oncogenes and/or correction of function of tumor-suppressor genes can inhibit tumor growth and induce apoptosis of tumor cells. Apoptotic signaling pathways are summarized in Fig. (2).

The functional loss of the tumor-suppressor p53 gene, the guardian of the genome, is the most common event in carcinogenesis [54]. p53 participates in several pathways of the cell cycle, including activation of genes that inhibit cell cycle progression into the $\mathrm{S}$ phase, promotion of DNA repair, and induction of apoptosis [55]. Point mutations of the p53 gene have been reported in more than $60 \%$ of gastric cancer cases and this leads to genetic instability and uncontrolled cell proliferation [56]. Restoration of p53 function has been shown to stabilize the malignant phenotype of neoplastic cells $[57,58]$. Overexpression of wild-type p53 induces growth arrest and/or apoptosis of p53-mutated gastric cancer cells in vitro [59]. Moreover, Ohashi et al. reported that p53-specific growth inhibition after transduction with adenoviruses encoding wild-type p53 was observed in vitro in two (MKN1 and MKN7) of four gastric cancer cell lines with mutated p53, but not in a wild-type p53 cell line (MKN45) [60]. The mechanism of gastric cancer cell death was found to be apoptosis. In this report, in vivo studies showed that the growth of subcutaneous tumors of p53 mutant MKN1 cells was inhibited by direct injection of an 
adenovirus, while no growth inhibition was observed in p53 wild-type MKN45 tumors. p51 (p73L/p63/p40/KET), a p53 homologue [61, 62], is another candidate of cancer gene therapy. p51 binds to p53-responsive elements to up-regulate some p53 target genes and has been suggested to share partially overlapping functions with p53 [63-65]. Kunisaki et al. tested the growth-suppressive effects of adenoviral transfer of p51A in several cancer cells including gastric cancer in vitro, and observed a significant anti-tumor effect on day 6 in all kinds of tumors analyzed irrespective of the expression level of endogenous p51 [66].

Cancer cells expressing wild-type p53 are relatively resistant to gene transfer of p53 [67] including gastric cancer cells [60]. Activation of p53 leads to G1 arrest through induction of p21 expression, or apoptosis by activation of bax expression; however, the latter does not occur in all cells [55]. Therefore, direct induction of apoptosis by proapoptotic gene transfer is rational. Bax is a strong proapoptotic gene that causes cytochrome $\mathrm{c}$ release from mitochondria and subsequently activates the caspase pathway leading to apoptosis [68, 69]. It was demonstrated that adenovirus-mediated bax gene transfer could effectively suppress tumor growth in both p53-sensitive and p53-resistant human lung carcinoma cell lines [70]. As for a gastric cancer model, Tsunemitsu et al. reported that adenoviral bax treatment was more effective in suppressing both subcutaneous and peritoneally disseminated MKN-45 tumors than p53 treatment [71]. On the other hand, down-regulation of anti-apoptotic genes is also an important strategy. Overexpression of the anti-apoptotic protein bcl-2 has been associated with drug resistance in various human malignancies; the expression of bcl-2 was down-regulated in chemotherapy responders, whereas its expression was increased or unchanged in non-responders [72, 73]. The 
introduction of the bcl-2 gene in vitro was followed by decreased drug sensitivity in tumor cells $[74,75]$. These findings suggest that bcl-2 affects responsiveness to chemotherapy in tumor cells. Overexpression of bcl-2 was confirmed in gastric carcinoma [76]. Kim et al. reported that down-regulation of bcl-2 by antisense bcl-2 enhanced the anti-tumor effect of cisplatin (CDDP) and paclitaxel in MKN45 gastric carcinoma xenografts in vivo [77]. In contrast, silencing bcl-XL, a bcl-2 family anti-apoptotic protein, by siRNA increased spontaneous apoptosis without simultaneous drug treatment in MGC-803 gastric carcinoma cells in vitro [78].

Rho family proteins, members of the Ras superfamily of small GTPases, have been shown to regulate several signal transduction pathways, and are involved in a variety of biological processes such as cell morphology [79, 80], motility [81], proliferation [82], and apoptosis [83]. Several reports have shown that RhoA expression is up-regulated in cancers, including gastric cancer [84]. Interleukin-6 (IL-6) can promote AGS gastric carcinoma cell motility and invasiveness via activation of the c-Src/RhoA/ROCK signaling pathway; thus, high expression of RhoA in gastric cancer cells is highly correlated with aggressive lymph node metastasis, more advanced tumor stage, histologically diffuse type and poor survival [85]. Liu et al. reported that inhibition of RhoA by RhoA-specific siRNA or dominant-negative RhoA expressions reversed the malignant phenotype of gastric cancer cells in vitro [86]. Sun et al. demonstrated that a combination of RhoA and RhoC siRNA-expressing adenoviral transfer could inhibit the proliferation and invasiveness activity of gastric carcinoma SGC7901 cells [87].

The Fas ligand (FasL), a member of the tumor necrosis factor family, initiates apoptosis by binding to its surface receptor Fas (CD95) and subsequent activation of caspase cascades [88]. 
Gastric carcinoma SGC-7901 cells infected with adenovirus encoding FasL resulted in decreased cell growth and colony-forming activity in vitro and in vivo tumor xenografts (intratumoral injection) [89]. Pro-caspase-8 is a downstream molecule of Fas and is activated by FasL-Fas binding [90]. Activated caspase-8 can activate executioner caspases such as caspase-3 [91]; therefore, caspase- 8 is attractive as a gene transfer candidate. However, overexpression of caspase- 8 can result in self-oligomerization and subsequent activation in the absence of any apoptotic signal [92], which leads to non-specific cell death. Nishimura et al. designed an adenovirus encoding pro-caspase- 8 for induction of anoikis, a kind of apoptosis in detached cells [93]. This system would act selectively against detached cells such as peritoneal dissemination of gastric carcinoma cells. In fact, they successfully demonstrated selective suppression of peritoneal dissemination with this system, while there were no distinct effects on cell viability or growth either of attached MKN45 cells or s.c. tumor growth in SCID mice. Gene transfer of the active form of executioner caspase-3 might more directly induce apoptosis of cancer cells. Srinivasula et al. generated constitutively active caspase- 3 by switching the order of its two subunits (and combining them with a linker) [94]. This reversed-caspase-3 (rev-caspase-3) was applied to gastric cancer cells and the growth of SGC7901 cells was suppressed in a time-dependent manner [95].

Nuclear factor-kappa B (NF- $\mathrm{B}$ ) is a family of stimulus-induced transcription factors

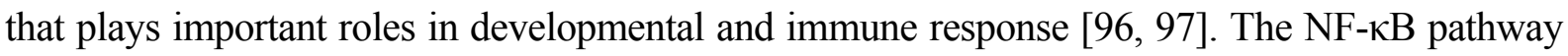
also has a role in tumor initiation, survival, and progression [98-101]. Tumor necrosis factor (TNF), a major mediator of apoptosis, also induces cell survival signals such as activation of 
$\mathrm{NF}-\kappa \mathrm{B}$ [102]. Blocking NF- $\mathrm{B}$ activation by inhibiting the activity of the proteasome enhanced TNF- $\alpha$-induced apoptosis in gastric cancer cell line [103]. On the other hand, Smad7 is an inhibitory Smad, blocking TGF- $\beta$-induced Smad activation, terminating the signaling pathway by feedback regulation [104]. In addition, Smad7 has other TGF- $\beta$-independent functions, as well as TGF- $\beta$-dependent functions. One of the TGF- $\beta$-independent functions of Smad7 is inhibition of $\mathrm{NF}-\kappa \mathrm{B}$ activation $[105,106]$. More recently, Hong et al. demonstrated that liposome-mediated transfection of Smad7 could overcome the TNF resistance in gastric cancer cells by inhibiting NF- $\kappa B$ activation [107].

The phosphatase and tensin homolog gene (PTEN), a tumor suppressor gene, is often mutated in various cancer cells [108]. Wild-type PTEN dephosphorylates the lipid second messenger phosphatidylinositol 3,4,5-triphosphate generated by phosphatidylinositol 3-kinase (PI3K) [109]. This function of PTEN negatively regulates PI3K/PKB/Akt-dependent cell survival, proliferation and migration $[110,111]$. Although both mutation and deletion of PTEN in gastric cancer account for few cases [112], adenovirus-mediated transfer of PTEN can suppress tumor growth in in vitro gastric cancer cells and in vivo tumor xenografts [113], suggesting that overexpression of PTEN may be effective for growth inhibition of gastric cancer cells which express wild-type PTEN.

Recently, it was reported that the tumor suppressor Fhit was a repressor of $\beta$-catenin transcriptional activity [114]. Clements et al. reported that $\beta$-catenin nuclear localization occurred in approximately $33 \%$ of gastric tumors and that $\beta$-catenin mutations occur in both diffuse- and intestinal-type gastric cancers [115]. Dumon et al. inhibited forestomach tumor development by 
oral gene transfer using adenoviral or adenoassociated viral vectors expressing the Fhit gene in Fhit-deficient mice [116]. The same group also found that reduced bcl-2, increased bax expression, and increased TUNEL-positive apoptotic nuclei characterized the restored epithelia of the Fhit-transduced forestomach [117]. On the other hand, Dvory-Sobol et al. constructed a recombinant adenoviral vector that carried a lethal gene (p53 up-regulated modulator of apoptosis, Puma) under the control of a $\beta$-catenin/T-cell factor (Tcf)-responsive promoter [118]. This vector inhibited cell growth in AGS gastric cancer cells that possessed an active $\beta$-catenin/Tcf pathway.

Survivin is expressed in mitosis in a cell cycle-dependent fashion [119]. It is potentially involved in both the inhibition of apoptosis and control of cell division [120, 121]. Tu et al. demonstrated that suppression of survivin expression in gastric cancer cells by stable transfection of an antisense-expressing plasmid or a dominant-negative mutant of survivin could inhibit in vivo tumorigenesis and angiogenesis after inoculation of these cells [122].

\section{Immunotherapy}

In cancer patients, immune responses against cancer cells are generally insufficient. To enhance anti-cancer immunity, gene transfer of cytokine gene(s) has been investigated [123, 124]. As for gastric cancer, it was reported that the tumorigenicity of gastric carcinoma cells engineered to produce IL-2 was reduced in SCID mice reconstituted with peripheral blood cells from cancer patients, while IL-6 had no such effect [125]. On the other hand, Tanaka et al. demonstrated that intraperitoneal IL-10 gene transfer to the peritoneal mesothelium using an adenoviral vector suppressed peritoneal dissemination of MKN45 gastric cancer cells [126]. However, IL-10 is an 
immunosuppressive cytokine $[127,128]$. In fact, Sakamoto et al. reported that the prognosis of patients with gastric cancer expressing IL-10 was significantly worse than those without IL-10 expression [129]. In addition, Lundin et al. showed that the peripheral blood T-cell response to $H$. pylori in gastric adenocarcinoma patients is characterized by decreased proliferation of $\mathrm{CD} 8^{+} \mathrm{T}$ cells and IFN- $\gamma$ production by $\mathrm{CD}^{+}{ }^{+} \mathrm{T}$ cells, and markedly increased production of IL-10 by cells both from the peripheral blood and gastric mucosa [130]. Therefore, further studies may be required on the usage of IL-10 prior to future clinical trials.

A DNA vaccine has the potential to induce specific, effective and persisting immunity against cancer [131]. A heterologous prime-boost strategy for effective generation of cellular immunity consists of priming the immune system by a first vector and selective boosting this immunity by a second and distinct vector [132]. Lin et al. developed a heterologous prime-boost regime using a first oral DNA vaccine (attenuated Salmonella typhimurium containing plasmid DNA) and a second adenoviral vaccine combined with a gastric cancer-specific tumor associated antigen MG7-Ag mimotope [133]. They successfully enhanced immune response against gastric cancer compared to a homologous prime-boost regime using an oral DNA vaccine or adenoviral vaccine alone.

Intercellular adhesion molecule (ICAM)-1 served as the counter-receptor for leukocyte function-associated antigen (LFA)-1 [134]. The ICAM-1/LFA-1 interaction is critical to the binding between effector cells and cancer cells, and ICAM-1 is a costimulatory molecule for immune activation [135]. Sunami et al. reported that transfection of the ICAM-1 gene inhibited lymph node metastasis of gastric cancer [136]. The same group also reported that gastric cancer 
cells overexpressing ICAM-1 have a tendency to cause regression of peritoneal dissemination [137]. In addition, ICAM-2, second ligand for LFA-1, has structural and functional homology to ICAM-1 [138]. Tanaka et al. demonstrated that intratumoral injection of adenoviral ICAM-2 inhibited the growth of s.c. gastric tumors, and also that mice with peritoneal metastasis survived for a longer time after adenoviral ICAM-2 transfer than controls [139].

\section{Anti-angiogenesis}

Angiogenesis is required for invasive tumor growth and metastasis because avascular tumors are severely restricted in their growth potential due to the lack of a blood supply. [140]. Various factors such as vascular endothelial growth factor (VEGF) and angiopoietin induce neovascularization in tumors [141]. A soluble form of the VEGF receptor (sFlt-1) reduces the effects of VEGF by trapping VEGF with high affinity [142]. Sako et al. demonstrated that a single intraperitoneal injection of an adenoviral vector encoding sFlt-1 prevented peritoneal dissemination of gastric cancer cells [39]. Hepatocyte growth factor (HGF) antagonist NK4 inhibits not only HGF receptor c-Met-mediated tumor growth, invasion and metastasis, but also the angiogenic responses induced by basic fibroblast growth factor, VEGF, and HGF [143, 144]. Two groups reported that adenoviral-mediated transfer of NK4 could suppress the tumor growth, invasion, angiogenesis [145], and peritoneal metastasis [40] of gastric cancer.

Angiostatin and endostatin are potent angiogenesis inhibitors. Angiostatin is a fragment of plasminogen [146]. Liposome-mediated transfection of the angiostatin gene in gastric cancer cells inhibited tumorigenesis in nude mice [147]. Endostatin is a fragment of collagen XVIII 
produced by hemangioendothelioma [148]. Zhang et al. constructed a gene therapy-virotherapy hybrid system CNHK300-mE, a replication-selective and transgene-expressing adenovirus carrying the mouse endostatin gene [149]. They demonstrated that the level of endostatin secreted from gastric cancer cells infected with CNHK300-mE was higher than those infected with a non-replicative adenovirus Ad-mE in vitro and in vivo. Furthermore, CNHK300-mE exhibited superior suppression of s.c. gastric cancer xenografts compared to CNHK300 and Ad-mE.

Hypoxia-inducible factor (HIF), a transcription factor, is an important upstream mediator of VEGF expression in cancer cells $[150,151]$. Stoeltzing et al. demonstrated that gastric cancer cells which were stably transfected with a dominant-negative form of HIF-1 $\alpha$ secreted less VEGF than a control [152]. In an s.c. tumor model, they also showed tumor growth and angiogenesis were suppressed. Therefore, HIF may be an attractive therapeutic target of gene therapy for gastric cancer using a dominant-negative form of HIF or HIF siRNA.

Rac1, a major member of the Rho GTPase family, is related to tumorigenesis [153], invasion and metastasis [154], and angiogenesis [81, 155]. Xue et al. showed that VEGF and HIF-1 $\alpha$ were down-regulated in gastric cancer cells which were transfected with a Rac1 siRNA expression vector [156]. Raf-1, an upstream molecule in the mitogen-activated protein kinase (MAPK) cascade, may also be involved in tumor angiogenesis [157]. The same group also showed similar results in gastric cancer cells with a Raf-1 siRNA expression vector [158].

\section{Other strategies}

Khare et al. delivered inducible nitric oxide (NO) synthase specifically to CEA-positive 
gastric cancer cells [15]. NO directly induces autocytotoxicity and cytolysis of bystander cells.

Synthesis of DNA at chromosome ends by telomerase may be necessary for indefinite proliferation of human cells [159]. Over the last decade, it has become clear that most human cancers activate telomerase at some point during tumorigenesis, while this activity is largely absent in most normal tissues [160]. Telomerase activity is also commonly positive in gastric cancer [56]. Inhibition of telomerase activity in MKN-45 gastric cancer cells by antisense human telomerase stable transfection induces apoptosis and growth arrest [161]. Ye et al. also reported growth inhibition effects of human telomerase antisense oligodeoxyribonucleotides in poorly differentiated MKN45 and moderately differentiated SGC-7901 gastric cancer cells, but not in well differentiated MKN-28 gastric cancer cells [162].

Heat shock proteins (HSPs), molecular chaperones, are induced by various stresses [163]. HSP70 is involved in the folding of nascent polypeptide chains and translocation of precursor proteins across the membranes of organelles [164]. HSP70 also interacts with mutated or altered oncogene and tumor suppressor gene products, which may be associated with development and progression of tumors $[165,166]$. HSP70 is overexpressed in gastric cancer, as well as in other tumors [167]. Zhao et al. demonstrated that HSP70 antisense oligodeoxyribonucleotides inhibited cell growth and induced apoptosis in gastric cancer cells [168]. On the contrary, HSPs is an activator of the innate immune system $[169,170]$ and can carry antigens to antigen-presenting cells [171]. Taking these functions of HSPs into consideration, a selective delivery system targeted to cancer cells will be required for down-regulation strategy of HSP70 in vivo. 


\section{Combination of several strategies}

Cancer cells should be completely killed; otherwise, recurrence and/or metastasis will occur. Therefore, the synergistic effects of combining several approaches are promising.

One attractive partner is chemotherapy. It was reported that the combination therapy of intratumoral administration of plasmid DNA encoding the bax gene complexed with a cationic lipopolyamine and the anti-cancer drugs 5-FU or CDDP significantly enhanced the anti-tumor effect in a gastric cancer model [172]. Takimoto et al. reported that histone deacetylase inhibitor such as sodium butylate could enhance the efficacy of an adenoviral vector carrying wild type p53 in gastric cancer cells by p53 activation and viral receptor up-regulation, in addition to its anti-tumor activity [173]. E2F-1, E2F family of transcription factor, has the ability to induce both cell cycle progression and apoptosis [174, 175]. Overexpression of E2F-1 by adenoviral gene transfer induced apoptosis in human gastric carcinoma cells, and this effect was enhanced by cyclin-dependent kinase inhibitors [176]. Namiki et al., demonstrated that NK4-expression by intraperitoneal injection of ternary complexes (plasmid DNA with cationic lipids and non-histone chromatin proteins) suppressed the gefitinib-resistance induced by the interaction between fibroblasts and scirrhous gastric cancer, and eventually, this tailor-made combination synergistically decelerated disease progression by inhibiting proliferative, angiogenic and anti-apoptotic effects in disseminated peritoneal tumor tissues [177]. Min et al. reported that the combination of dominant-negative insulin-like growth factor I receptor expression using an adenoviral vector and chemotherapy was very effective against gastric cancer xenografts in vivo [178]. Guo et al. constructed a combination of HSV-tk with a cytokine gene (IL-2 and 
granulocyte macrophage colony-stimulating factor) and showed a strong anti-tumor effect in a gastric cancer model [179]. In addition, several groups overcame drug resistance by gene delivery. Zhang et al. reported that ZNRD1 (zinc ribbon domain-containing 1 protein) antisense nucleic acid transfection sensitized drug-resistant gastric cancer cells to vincristine, increased adriamycin accumulation and inhibited cell proliferation [180]. Guo et al. demonstrated that overexpression of the tumor suppressor Runx3 gene could sensitize gastric cancer cells to chemotherapeutic drugs by down-regulating not only bcl-2, but also MDR-1 and MRP-1 [181].

Virotherapy using conditionally replicative viruses is a newly developed therapeutic option for cancer $[182,183]$. This approach is easily combined with gene therapy by genetic modification of the same viruses. Zhang et al. developed a combination of oncolysis with virotherapy targeted to telomerase-positive cancers, and anti-angiogenesis by gene therapy using an endostatin gene [149].

Combination of gene therapy with radiation has also great potential to treat several cancers [184] including gastric cancer [178].

\section{APPROACHES TO TREAT GASTRIC ULCER}

A gastric ulcer is a deep necrotic lesion penetrating through the entire mucosal thickness, the muscularis mucosae, and often involves the muscularis propria [185]. Ulcer healing, a genetically programmed repair process, includes inflammation, cell proliferation, re-epithelialization, formation of granulation tissue, angiogenesis, interactions between various cells and the matrix and tissue remodeling, all resulting in scar formation [186]. Because VEGF 
and angiopoietin-1 are involved in angiogenesis, Jones et al. studied whether local gene therapy with naked DNA encoding these genes into the ulcer base could accelerate ulcer healing through enhanced angiogenesis [187]. They successfully demonstrated accelerated gastric ulcer healing. Co-injection of both genes led to more complete structural restoration. The same group also demonstrated that gene therapy with a serum response factor accelerated experimental gastric ulcer healing and promoted re-epithelialization and muscle restoration [188]. Finally, local injection of plasmid DNA encoding the cationic host defense peptide cathelicidin promoted gastric ulcer healing by enhancing cell proliferation and angiogenesis [189]. 


\section{CONCLUSION}

In this review, we summarized stomach- and cancer-targeted gene transfer methods and therapeutic strategies for gastric diseases, including cancer and ulcer. Since gene expression in non-target tissues/cells can cause side effects, selective gene delivery systems targeted to the stomach and/or cancer cells must be developed. The route of vector transfer is an important issue which can determine efficacy and safety.

H. pylori activate NF- $\mathrm{BB}$ via MAPK cascades, as a consequence IL-8 release from AGS gastric cancer cells [190] and macrophages [191] occur. IL-8 is a chemoattractant, which stimulate significant infiltration of neutrophils into gastric mucosa, leading to chronic gastritis. IL-8 is also a mediator of angiogenesis [192]. H. pylori increased expression of mRNAs encoding not only IL-8, but also VEGF, angiogenin, urokinase-type plasminogen activator, and metalloproteinase- 9 by gastric carcinoma cells, suggested that $H$. pylori infection might regulate angiogenesis and invasion of human gastric carcinoma [193]. As future prospects, suppression of these genes by antisense or siRNA may inhibit tumor progression and angiogenesis caused by $H$. pylori infection.

Tumor-associated macrophages (TAMs) have been shown to be symbiotically related to tumor cells; tumor cells recruit TAMs and provide them with survival factors, and in turn TAMs produce a variety of angiogenic factors in response to the tumor microenvironment [194]. Ishigami et al. reported that the degree of infiltration of TAMs positively correlated with depth of invasion, nodal status and clinical stage in gastric cancer patients [195]. Therefore, TAMs may be a potent target of gene therapy for gastric cancer as well as other cancer. As to targeted delivery to 
macrophages, Kawakami et al. developed mannosylated cationic liposome/plasmid DNA complex and they successfully delivered foreign gene to macrophages in mice [196]. As well, a dominant negative monocyte chemoattractant-1 mutant (7ND) treatment inhibited TAMs recruitment and partially reduced angiogenesis and growth of melanoma [197], thus, this might also be effective for gastric cancer.

As for gastric cancer, investigations were performed mainly in vitro gastric cancer cell lines. Some investigations showed in vivo therapeutic effects in s.c. tumor xenografts of gastric cancer cells; however, there are strong doubts about their efficacy in primary gastric cancer. In contrast, gene therapy for peritoneal dissemination of gastric cancer is promising since good results were reported in an animal model similar to the in vivo situation. Prophylactic usage of gene therapy after surgical resection may improve patient prognosis. For this purpose, an oral gene delivery system or controlled release formula of gene medicine should be developed. 


\section{REFERENCES}

[1] Parkin DM, Bray F, Ferlay J, Pisani P. Global cancer statistics, 2002. CA Cancer J Clin 55: 74-108 (2005).

[2] Wanebo HJ, Kennedy BJ, Chmiel J, Steele G Jr, Winchester D, Osteen R. Cancer of the stomach. A patient care study by the American College of Surgeons. Ann Surg 218: 583-592 (1993).

[3] Robbins PD, Ghivizzani SC. Viral vectors for gene therapy. Pharmacol Ther 80: 35-47 (1998).

[4] Kay MA, Glorioso JC, Naldini L. Viral vectors for gene therapy: the art of turning infectious agents into vehicles of therapeutics. Nat Med 7: 33-40 (2001).

[5] Kaplan JM. Adenovirus-based cancer gene therapy. Curr Gene Ther 5: 595-605 (2005).

[6] Nishikawa M, Huang L. Nonviral vectors in the new millennium: delivery barriers in gene transfer. Hum Gene Ther 12: 861-870 (2001).

[7] Hashida M, Kawakami S, Yamashita F. Lipid carrier systems for targeted drug and gene delivery. Chem Pharm Bull 53: 871-880 (2005).

[8] Ohlfest JR, Freese AB, Largaespada DA. Nonviral vectors for cancer gene therapy: prospects for integrating vectors and combination therapies. Curr Gene Ther 5: 629-641 (2005).

[9] Marshall E. Gene therapy death prompts review of adenovirus vector. Science 286: 2244-2245 (1999).

[10] Check E. A tragic setback. Nature 420: 116-118 (2002).

[11] Wagner RW. Gene inhibition using antisense oligodeoxynucleotides. Nature 372: 333-335 (1994). 
[12] Elbashir SM, Harborth J, Lendeckel W, Yalcin A, Weber K, Tuschl T. Duplexes of 21-nucleotide RNAs mediate RNA interference in cultured mammalian cells. Nature 411: 494-498 (2001).

[13] Valencia-Sanchez MA, Liu J, Hannon GJ, Parker R. Control of translation and mRNA degradation by miRNAs and siRNAs. Genes Dev 20: 515-524 (2006).

[14] Ohuchi N, Wunderlich D, Fujita J, et al. Differential expression of carcinoembryonic antigen in early gastric adenocarcinomas versus benign gastric lesions defined by monoclonal antibodies reactive with restricted antigen epitopes. Cancer Res 47: 3565-3571 (1987).

[15] Khare PD, Shao-Xi L, Kuroki M, et al. Specifically targeted killing of carcinoembryonic antigen (CEA)-expressing cells by a retroviral vector displaying single-chain variable fragmented antibody to CEA and carrying the gene for inducible nitric oxide synthase. Cancer Res 61: 370-375 (2001).

[16] Tanaka T, Huang J, Hirai S, et al. Carcinoembryonic antigen-targeted selective gene therapy for gastric cancer through FZ33 fiber-modified adenovirus vectors. Clin Cancer Res 12: 3803-3813 (2006).

[17] Heideman DAM, Snijders PJF, Craanen ME, et al. Selective gene delivery toward gastric and esophageal adenocarcinoma cells via EpCAM-targeted adenoviral vectors. Cancer Gene Ther 8: 342-351 (2001).

[18] Tanaka T, Kanai F, Okabe S, et al. Adenovirus-mediated prodrug gene therapy for carcinoembryonic antigen-producing human gastric carcinoma cells in vitro. Cancer Res 56: 1341-1345 (1996). 
[19] Tanaka T, Kanai F, Lan KH, et al. (1997) Adenovirus-mediated gene therapy of gastric carcinoma using cancer-specific gene expression in vivo. Biochem Biophys Res Commun 231: 775-779.

[20] Lan KH, Kanai F, Shiratori Y, et al. In vivo selective gene expression and therapy mediated by adenoviral vectors for human carcinoembryonic antigen-producing gastric carcinoma. Cancer Res 57: 4279-4284 (1997).

[21] Ueda K, Iwahashi M, Nakamori M, et al. Carcinoembryonic antigen-specific suicide gene therapy of cytosine deaminase/5-fluorocytosine enhanced by the Cre/loxP system in the orthotopic gastric carcinoma model. Cancer Res 61: 6158-6162 (2001).

[22] Dubois RN, Abramson SB, Crofford L, et al. Cyclooxygenase in biology and disease. FASEB J 12: 1063-1073 (1998).

[23] Williams C, Shattuck-Brandt RL, DuBois RN. The role of COX-2 in intestinal cancer. Ann N Y Acad Sci 889: 72-83 (1999).

[24] Ristimäki A, Honkanen N, Jänkälä H, Sipponen P, Härkönen M. Expression of cyclooxygenase-2 in human gastric carcinoma. Cancer Res 57: 1276-1280 (1997).

[25] Yamamoto M, Alemany R, Adachi Y, Grizzle WE, Curiel DT. Characterization of the cyclooxygenase- 2 promoter in an adenoviral vector and its application for the mitigation of toxicity in suicide gene therapy of gastrointestinal cancers. Mol Ther 3:385-394 (2001).

[26] Gao JQ, Eto Y, Yoshioka Y, et al. Effective tumor targeted gene transfer using PEGylated adenovirus vector via systemic administration. J Control Release 122: 102-110 (2007).

[27] Maeda H. The enhanced permeability and retention (EPR) effect in tumor vasculature: the 
key role of tumor-selective macromolecular drug targeting. Adv Enzyme Regul 41: 189-207 (2001).

[28] Zhao XB, Lee RJ. Tumor-selective targeted delivery of genes and antisense oligodeoxyribonucleotides via the folate receptor. Adv Drug Deliv Rev 56: 1193-1204 (2004).

[29] van Beusechem VW, Grill J, Mastenbroek DCJ, et al. Efficient and selective gene transfer into primary human brain tumors by using single-chain antibody-targeted adenoviral vectors with native tropism abolished. J Virol 76: 2753-2762 (2002).

[30] Liu Y, Koziol J, Deisseroth A, Borgstrom, P. Methods for delivery of adenoviral vectors to tumor vasculature. Hum Gene Ther 18: 151-160 (2007).

[31] Wolff JA, Malone RW, Williams P, Chong W, Acsadi G, Jani A, Felgner PL. Direct gene transfer into mouse muscle in vivo. Science 247: 1465-1468 (1990).

[32] Hickman MA, Malone RW, Lehmann-Bruinsma K, et al. Gene expression following direct injection of DNA into liver. Hum Gene Ther 5: 1477-1483 (1994).

[33] Li K, Welikson RE, Vikstrom KL, Leinwand LA. Direct gene transfer into the mouse heart. J. Mol Cell Cardiol 29: 1499-1504 (1997).

[34] White SA, LoBuglio AF, Arani RB., et al. Induction of anti-tumor immunity by intrasplenic administration of a carcinoembryonic antigen DNA vaccine. J Gene Med 2: 135-140 (2000).

[35] Nomura T, Yasuda K, Yamada T, et al. Gene expression and antitumor effects following direct interferon (IFN)- $\gamma$ gene transfer with naked plasmid DNA and DC-chol liposome complexes in mice. Gene Ther 6: 121-129 (1999). 
[36] Takehara T, Hayashi N, Yamamoto M, Miyamoto Y, Fusamoto H, Kamada T. In vivo gene transfer and expression in rat stomach by submucosal injection of plasmid DNA. Hum Gene Ther 7: 589-593 (1996).

[37] Haraguchi M, Watanabe A, Kakeji Y, et al. Prognostic significance of serosal invasion in carcinoma of the stomach. Surg Gynecol Obstet 172: 29-32 (1991).

[38] Shiraishi N, Sato K, Yasuda K, Inomata M, Kitano S. Multivariate prognostic study on large gastric cancer. J Surg Oncol 96: 14-18 (2007).

[39] Sako A, Kitayama J, Koyama, H., et al. Transduction of soluble Flt-1 gene to peritoneal mesothelial cells can effectively suppress peritoneal metastasis of gastric cancer. Cancer Res 64: 3624-3628 (2004).

[40] Ueda K, Iwahashi M, Matsuura I, et al. Adenoviral-mediated gene transduction of the hepatocyte growth factor (HGF) antagonist, NK4, suppresses peritoneal metastases of gastric cancer in nude mice. Eur J Cancer 40: 2135-2142 (2004).

[41] Kawakami S, Hirayama R, Shoji K, et al. Liver- and lobe-selective gene transfection following the instillation of plasmid DNA to the liver surface in mice. Biochem Biophys Res Commun 294: 46-50 (2002).

[42] Hirayama R, Nishida K, Fumoto S, Nakashima M, Sasaki H, Nakamura J. Unilateral kidney-selective gene transfer following the administration of naked plasmid DNA to the kidney surface in mice. Biol Pharm Bull 28: 181-184 (2005).

[43] Nakamura J, Fumoto S, Kawanami R, et al. Spleen-selective gene transfer following the administration of naked plasmid DNA onto the spleen surface in mice. Biol Pharm Bull 30: 
941-945 (2007).

[44] Nakamura J, Fumoto S, Ariyoshi K, et al. Unilateral lung-selective gene transfer following the administration of naked plasmid DNA onto the pulmonary pleural surface in mice. Biol Pharm Bull 30: 729-732 (2007).

[45] Nakamura, J., Fumoto, S., Shoji, K., et al. Stomach-selective gene transfer following the administration of naked plasmid DNA onto the gastric serosal surface in mice. Biol Pharm Bull 29: 2082-2086 (2006).

[46] Nishi J, Fumoto S, Ishii H, et al. Improved stomach selectivity of gene expression following microinstillation of plasmid DNA onto the gastric serosal surface in mice. Eur $\mathrm{J}$ Pharm Biopharm, in press (doi:10.1016/j.ejpb.2007.12.018).

[47] Nakamura J, Kobayashi K, Fumoto S, et al. (2005) Stomach- and site-selective delivery of 5-fluorouracil following its application on the gastric serosal surface in rats. Biol Pharm Bull 28: 1049-1053.

[48] Shao G, Greathouse K, Huang Q, Wang CM, Sferra TJ. Gene transfer to the gastrointestinal tract after peroral administration of recombinant adeno-associated virus type 2 vectors. $\mathrm{J}$ Pediatr Gastroenterol Nutr 43: 168-179 (2006).

[49] Guliyeva Ü, Öner F, Özsoy Ş, Haziroğlu R. Chitosan microparticles containing plasmid DNA as potential oral gene delivery system. Eur J Pharm Biopharm 62: 17-25 (2006).

[50] Zheng F, Shi XW, Yang GF, et al. Chitosan nanoparticle as gene therapy vector via gastrointestinal mucosa administration: results of an in vitro and in vivo study. Life Sci 80: 388-396 (2007). 
[51] Bhavsar MD, Amiji, MM. Gastrointestinal distribution and in vivo gene transfection studies with nanoparticles-in-microsphere oral system (NiMOS). J Control Release 119: 339-348 (2007).

[52] Schepelmann S, Springer CJ. Viral vectors for gene-directed enzyme prodrug therapy. Curr Gene Ther 6: 647-670 (2006).

[53] Freeman SM., Abboud CN, Whartenby KA, et al. The "bystander effect": tumor regression when a fraction of the tumor mass is genetically modified. Cancer Res 53: 5274-5283 (1993).

[54] Weinberg RA. Tumor suppressor genes. Science 254: 1138-1146 (1991).

[55] Levine AJ. p53, the cellular gatekeeper for growth and division. Cell 88: 323-331 (1997).

[56] Tahara E, Semba S, Tahara H. Molecular biological observations in gastric cancer. Semin Oncol 23: 307-315 (1996).

[57] Baker SJ, Markowitz S, Fearon, ER, Willson JK, Vogelstein B. Suppression of human colorectal carcinoma cell growth by wild-type p53. Science 249: 912-915 (1990).

[58] Mercer WE, Shields MT, Amin M, et al. (1990) Negative growth regulation in a glioblastoma tumor cell line that conditionally expresses human wild-type p53. Proc Natl Acad Sci USA 87: 6166-6170.

[59] Matozaki T, Sakamoto C, Suzuki T, et al. p53 gene mutations in human gastric cancer: wild-type p53 but not mutant p53 suppresses growth of human gastric cancer cells. Cancer Res 52: 4335-4341 (1992).

[60] Ohashi M, Kanai F, Ueno H, et al. (1999) Adenovirus mediated p53 tumour suppressor gene therapy for human gastric cancer cells in vitro and in vivo. Gut 44: 366-371. 
[61] Kaghad M, Bonnet H, Yang A, et al. (1997) Monoallelically expressed gene related to p53 at 1p36, a region frequently deleted in neuroblastoma and other human cancers. Cell 90: 809-819.

[62] Osada M, Ohba M, Kawahara C, et al. Cloning and functional analysis of human p51, which structurally and functionally resembles p53. Nat Med 4: 839-843 (1998).

[63] Shimada A, Kato S, Enjo K, et al. The transcriptional activities of p53 and its homologue p51/p63: similarities and differences. Cancer Res 59: 2781-2786 (1999).

[64] Ishida S, Yamashita T, Nakaya U, Tokino T. Adenovirus-mediated transfer of p53-related genes induces apoptosis of human cancer cells. Jpn J Cancer Res 91: 174-180 (2000).

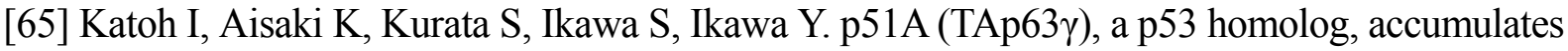
in response to DNA damage for cell regulation. Oncogene 19: 3126-3130 (2000).

[66] Kunisaki R, Ikawa S, Maeda T, et al. p51/p63, a novel p53 homologue, potentiates p53 activity and is a human cancer gene therapy candidate. J Gene Med 8: 1121-1130 (2006).

[67] Harris MP, Sutjipto S, Wills KN, et al. Adenovirus-mediated p53 gene transfer inhibits growth of human tumor cells expressing mutant p53 protein. Cancer Gene Ther 3: 121-130 (1996).

[68] Jürgensmeier JM, Xie Z, Deveraux Q, Ellerby L, Bredesen D, Reed JC. Bax directly induces release of cytochrome c from isolated mitochondria. Proc Natl Acad Sci USA 95: 4997-5002 (1998).

[69] Pastorino JG, Chen ST, Tafani M, Snyder JW, Farber JL. The overexpression of Bax produces cell death upon induction of the mitochondrial permeability transition. J Biol Chem 
273: 7770-7775 (1998).

[70] Kagawa S, Gu J, Swisher SG, et al. Antitumor effect of adenovirus-mediated Bax gene transfer on p53-sensitive and p53-resistant cancer lines. Cancer Res 60: 1157-1161 (2000).

[71] Tsunemitsu Y, Kagawa S, Tokunaga N, et al. Molecular therapy for peritoneal dissemination of xenotransplanted human MKN-45 gastric cancer cells with adenovirus mediated Bax gene transfer. Gut 53: 554-560 (2004).

[72] Cleator S, Parton M, Dowsett M. The biology of neoadjuvant chemotherapy for breast cancer. Endocr Relat Cancer 9: 183-195 (2002).

[73] Buchholz TA, Davis DW, McConkey DJ, et al. Chemotherapy-induced apoptosis and Bcl-2 levels correlate with breast cancer response to chemotherapy. Cancer J 9: 33-41 (2003).

[74] Chaudhary KS, Abel PD, Stamp GWH, Lalani EN. Differential expression of cell death regulators in response to thapsigargin and adriamycin in Bcl-2 transfected DU145 prostatic cancer cells. J Pathol 193: 522-529 (2001).

[75] Sartorius UA, Krammer PH. Upregulation of Bcl-2 is involved in the mediation of chemotherapy resistance in human small cell lung cancer cell lines. Int J Cancer 97: 584-592 (2002).

[76] Konturek PC, Konturek SJ, Sulekova Z, et al. Expression of hepatocyte growth factor, transforming growth factor alpha, apoptosis related proteins Bax and Bcl-2, and gastrin in human gastric cancer. Aliment Pharmacol Ther 15: 989-999 (2001).

[77] Kim R, Emi M, Tanabe K, Toge T. Preclinical evaluation of antisense bcl-2 as a chemosensitizer for patients with gastric carcinoma. Cancer 101: 2177-2186 (2004). 
[78] Lei XY, Zhong M, Feng LF, et al. Silencing of Bcl-XL expression in human MGC-803 gastric cancer cells by siRNA. Acta Biochim Biophys Sin 37: 555-560 (2005).

[79] Paterson HF, Self AJ, Garrett MD, Just I, Aktories K, Hall A. Microinjection of recombinant p2 $1^{\text {rho }}$ induces rapid changes in cell morphology. J Cell Biol 111: 1001-1007 (1990).

[80] Ramakers GJA, Moolenaar WH. Regulation of astrocyte morphology by RhoA and lysophosphatidic acid. Exp Cell Res 245: 252-262 (1998).

[81] Soga N, Namba N, McAllister S, et al. Rho family GTPases regulate VEGF-stimulated endothelial cell motility. Exp Cell Res 269: 73-87 (2001).

[82] Sahai E, Olson MF, Marshall CJ. Cross-talk between Ras and Rho signalling pathways in transformation favours proliferation and increased motility. EMBO J 20: 755-766 (2001).

[83] Senger DL, Tudan C, Guiot MC, et al. Suppression of Rac activity induces apoptosis of human glioma cells but not normal human astrocytes. Cancer Res 62: 2131-2140 (2002).

[84] Pan Y, Bi F, Liu N, et al. Expression of seven main Rho family members in gastric carcinoma. Biochem Biophys Res Commun 315: 686-691 (2004).

[85] Lin MT, Lin BR, Chang CC, et al. IL-6 induces AGS gastric cancer cell invasion via activation of the c-Src/RhoA/ROCK signaling pathway. Int J Cancer 120: 2600-2608 (2007).

[86] Liu N, Bi F, Pan Y, et al. Reversal of the malignant phenotype of gastric cancer cells by inhibition of RhoA expression and activity. Clin Cancer Res 10: 6239-6247 (2004).

[87] Sun HW, Tong SL, He J, et al. RhoA and RhoC -siRNA inhibit the proliferation and invasiveness activity of human gastric carcinoma by Rho/PI3K/Akt pathway. World $\mathrm{J}$ Gastroenterol 13: 3517-3522 (2007). 
[88] Kavurma MM, Khachigian LM. Signaling and transcriptional control of Fas ligand gene expression. Cell Death Differ 10: 36-44 (2003).

[89] Zheng SY, Li DC, Zhang ZD, Zhao J, Ge JF. Adenovirus-mediated FasL gene transfer into human gastric carcinoma. World J Gastroenterol 11: 3446-3450 (2005).

[90] Thorburn A. Death receptor-induced cell killing. Cell Signal 16: 139-144 (2004).

[91] Stennicke HR, Jürgensmeier JM, Shin H, et al. Pro-caspase-3 is a major physiologic target of caspase-8. J Biol Chem 273: 27084-27090 (1998).

[92] Martin DA, Siegel RM, Zheng L, Lenardo MJ. Membrane oligomerization and cleavage activates the caspase-8 (FLICE/MACH $\alpha 1$ ) death signal. J Biol Chem 273: 4345-4349 (1998).

[93] Nishimura S, Adachi M, Ishida T, et al. Adenovirus-mediated transfection of caspase-8 augments anoikis and inhibits peritoneal dissemination of human gastric carcinoma cells. Cancer Res 61: 7009-7014 (2001).

[94] Srinivasula SM, Ahmad M, MacFarlane M, et al. Generation of constitutively active recombinant caspases-3 and -6 by rearrangement of their subunits. J Biol Chem 273: 10107-10111 (1998).

[95] Fu YG, Qu YJ, Wu KC, Zhai HH, Liu ZG, Fan DM. Apoptosis-inducing effect of recombinant Caspase-3 expressed by constructed eukaryotic vector on gastric cancer cell line SGC7901. World J Gastroenterol 9: 1935-1939 (2003).

[96] McKay LI, Cidlowski JA. Molecular control of immune/inflammatory responses: interactions between nuclear factor- $\mathrm{B}$ and steroid receptor-signaling pathways. Endocr Rev 
20: 435-459 (1999).

[97] Weih F, Caamaño J. Regulation of secondary lymphoid organ development by the nuclear factor-kB signal transduction pathway. Immunol Rev 195: 91-105 (2003).

[98] Greten FR, Eckmann L, Greten TF, et al. IKK $\beta$ links inflammation and tumorigenesis in a mouse model of colitis-associated cancer. Cell 118: 285-296 (2004).

[99] Luo JL, Maeda S, Hsu LC, Yagita H, Karin M. Inhibition of NF- $\kappa B$ in cancer cells converts inflammation- induced tumor growth mediated by TNFa to TRAIL-mediated tumor regression. Cancer Cell 6: 297-305 (2004).

[100] Pikarsky E, Porat RM, Stein I, et al. (2004) NF-kB functions as a tumour promoter in inflammation-associated cancer. Nature 431: 461-466.

[101] Libermann TA, Zerbini LF. Targeting transcription factors for cancer gene therapy. Curr Gene Ther 6: 17-33 (2006).

[102] Chen G, Goeddel DV. TNF-R1 signaling: a beautiful pathway. Science 296: 1634-1635 (2002).

[103] Ueda M, Kokura S, Imamoto E, et al. (2003) Blocking of NF- $\kappa B$ activation enhances the tumor necrosis factor $\alpha$-induced apoptosis of a human gastric cancer cell line. Cancer Lett 193: $177-182$.

[104] Miyazono K, ten Dijke P, Heldin CH. TGF- $\beta$ signaling by Smad proteins. Adv Immunol 75: $115-157(2000)$

[105] Wang W, Huang XR, Li AG, et al. Signaling mechanism of TGF- $\beta 1$ in prevention of renal inflammation: role of Smad7. J Am Soc Nephrol 16: 1371-1383 (2005). 
[106] Hong S, Lim S, Li AG, et al. Smad7 binds to the adaptors TAB2 and TAB3 to block recruitment of the kinase TAK1 to the adaptor TRAF2. Nat Immunol 8: 504-513 (2007).

[107] Hong S, Lee C, Kim SJ. Smad7 sensitizes tumor necrosis factor induced apoptosis through the inhibition of antiapoptotic gene expression by suppressing activation of the nuclear factor-кB pathway. Cancer Res 67: 9577-9583 (2007).

[108] Li J, Yen C, Liaw D, et al. PTEN, a putative protein tyrosine phosphatase gene mutated in human brain, breast, and prostate cancer. Science 275: 1943-1947 (1997).

[109] Maehama T, Dixon JE. The tumor suppressor, PTEN/MMAC1, dephosphorylates the lipid second messenger, phosphatidylinositol 3,4,5-trisphosphate. J Biol Chem 273: 13375-13378 (1998).

[110] Stambolic V, Suzuki A, de la Pompa JL, et al. Negative regulation of PKB/Akt-dependent cell survival by the tumor suppressor PTEN. Cell 95: 29-39 (1998).

[111] Yamada KM, Araki M. Tumor suppressor PTEN: modulator of cell signaling, growth, migration and apoptosis. J Cell Sci 114: 2375-2382 (2001).

[112] Sato K, Tamura G, Tsuchiya T, et al. Analysis of genetic and epigenetic alterations of the PTEN gene in gastric cancer. Virchows Arch 440: 160-165 (2002).

[113] Hang Y, Zheng YC, Cao Y, Li QS, Sui YJ. Suppression of gastric cancer growth by adenovirus-mediated transfer of the PTEN gene. World J Gastroenterol 11: 2224-2229 (2005).

[114] Weiske J, Albring KF, Huber O. The tumor suppressor Fhit acts as a repressor of $\beta$-catenin transcriptional activity. Proc Natl Acad Sci USA 104: 20344-20349 (2007). 
[115] Clements WM, Wang J, Sarnaik A, et al. $\beta$-Catenin mutation is a frequent cause of Wnt pathway activation in gastric cancer. Cancer Res 62: 3503-3506 (2002).

[116] Dumon KR, Ishii H, Fong LYY, et al. FHIT gene therapy prevents tumor development in Fhit-deficient mice. Proc Natl Acad Sci USA 98: 3346-3351 (2001).

[117] Ishii H, Zanesi N, Vecchione A, et al. Regression of upper gastric cancer in mice by FHIT gene delivery. FASEB J 17: 1768-1770 (2003).

[118] Dvory-Sobol H, Sagiv E, Liberman E, Kazanov D, Arber N. Suppression of gastric cancer cell growth by targeting the $\beta$-catenin/T-cell factor pathway. Cancer 109: 188-197 (2007).

[119] Li F, Ambrosini G, Chu EY, et al. (1998) Control of apoptosis and mitotic spindle checkpoint by survivin. Nature 396: 580-584.

[120] Reed JC, Bischoff JR. BIRinging chromosomes through cell division-and survivin' the experience. Cell 102: 545-548 (2000).

[121] Giodini A, Kallio MJ, Wall NR, et al. Regulation of microtubule stability and mitotic progression by survivin. Cancer Res 62: 2462-2467 (2002).

[122] Tu SP, Jiang XH, Lin MCM, et al. Suppression of survivin expression inhibits in vivo tumorigenicity and angiogenesis in gastric cancer. Cancer Res 63: 7724-7732 (2003).

[123] Tahara H, Lotze MT. Antitumor effects of interleukin-12 (IL-12): applications for the immunotherapy and gene therapy of cancer. Gene Ther 2: 96-106 (1995).

[124] Larin SS, Georgiev GP, Kiselev SL. Gene transfer approaches in cancer immunotherapy. Gene Ther 11 Suppl 1: S18-25 (2004).

[125] Tagawa M, Goto S, Takenaga K, et al. Reduced tumorigenicity of human gastric carcinoma 
cells engineered to produce IL-2 in SCID mice reconstituted with peripheral blood cells from cancer patients. Cancer Lett 123: 87-93 (1998).

[126] Tanaka F, Tominaga K, Shiota M, et al. Interleukin-10 gene transfer to peritoneal mesothelial cells suppresses peritoneal dissemination of gastric cancer cells due to a persistently high concentration in the peritoneal cavity. Cancer Gene Ther 15: $51-59$ (2008).

[127] Abbas AK, Murphy KM, Sher A. Functional diversity of helper T lymphocytes. Nature 383: 787-793 (1996).

[128] Kim R, Emi M, Tanabe K. Cancer immunosuppression and autoimmune disease: beyond immunosuppressive networks for tumour immunity. Immunology 119: 254-264 (2006).

[129] Sakamoto T, Saito H, Tatebe S, et al. Interleukin-10 expression significantly correlates with minor $\mathrm{CD}^{+} \mathrm{T}$-cell infiltration and high microvessel density in patients with gastric cancer. Int J Cancer 118: 1909-1914 (2006).

[130] Lundin BS, Enarsson K, Kindlund B, et al. The local and systemic T-cell response to Helicobacter pylori in gastric cancer patients is characterised by production of interleukin- 10 . Clin Immunol 125: 205-213 (2007).

[131] Gurunathan S, Klinman DM, Seder RA. DNA vaccines: immunology, application, and optimization. Annu Rev Immunol 18: $927-974$ (2000).

[132] Woodland DL. Jump-starting the immune system: prime-boosting comes of age. Trends Immunol 25: 98-104 (2004).

[133] Lin, T., Liang, S., Meng, F., et al. Enhanced immunogenicity and antitumour effects with heterologous prime-boost regime using vaccines based on MG7-Ag mimotope of gastric 
cancer. Clin Exp Immunol 144: 319-325 (2006).

[134] Hildreth JEK, Gotch FM, Hildreth PDK, McMichael AJ. A human lymphocyte-associated antigen involved in cell-mediated lympholysis. Eur J Immunol 13: 202-208 (1983).

[135] Chong AS, Boussy IA, Jiang XL, Lamas M, Graf LH Jr. CD54/ICAM-1 is a costimulator of NK cell-mediated cytotoxicity. Cell Immunol 157: 92-105 (1994).

[136] Sunami T, Yashiro M, Hirakawa-Y.-S. Chung K. ICAM-1 (intercellular adhesion molecule-1) gene transfection inhibits lymph node metastasis by human gastric cancer cells. Jpn J Cancer Res 91: 925-933 (2000).

[137] Tanaka H, Yashiro M, Sunami T, Ohira M, Hirakawa-Y.-S. Chung K. Lipid-mediated gene transfection of intercellular adhesion molecule-1 suppresses the peritoneal metastasis of gastric carcinoma. Int J Mol Med 10: 613-617 (2002).

[138] Staunton DE, Dustin ML, Springer TA. Functional cloning of ICAM-2, a cell adhesion ligand for LFA-1 homologous to ICAM-1. Nature 339: 61-64 (1989).

[139] Tanaka H, Yashiro M, Sunami T, Sakate Y, Kosaka K, Hirakawa K. ICAM-2 gene therapy for peritoneal dissemination of scirrhous gastric carcinoma. Clin Cancer Res 10: 4885-4892 (2004).

[140] Folkman J. Role of angiogenesis in tumor growth and metastasis. Semin Oncol 29: 15-18 (2002).

[141] Saaristo A, Karpanen T, Alitalo K. Mechanisms of angiogenesis and their use in the inhibition of tumor growth and metastasis. Oncogene 19: 6122-6129 (2000).

[142] Kendall RL, Wang G, Thomas KA. Identification of a natural soluble form of the vascular 
endothelial growth factor receptor, FLT-1, and its heterodimerization with KDR. Biochem Biophys Res Commun 226: 324-328 (1996).

[143] Date K, Matsumoto K, Shimura H, Tanaka M, Nakamura T. HGF/NK4 is a specific antagonist for pleiotrophic actions of hepatocyte growth factor. FEBS Lett 420: 1-6 (1997).

[144] Matsumoto K, Nakamura T. NK4 (HGF-antagonist/angiogenesis inhibitor) in cancer biology and therapeutics. Cancer Sci 94: 321-327 (2003).

[145] Heideman, DAM, van Beusechem VW, Bloemena E, et al. Suppression of tumor growth, invasion and angiogenesis of human gastric cancer by adenovirus-mediated expression of NK4. J Gene Med 6: 317-327 (2004).

[146] O'Reilly MS, Holmgren L, Shing Y, et al. Angiostatin: a novel angiogenesis inhibitor that mediates the suppression of metastases by a Lewis lung carcinoma. Cell 79: 315-328 (1994).

[147] Wu J, Shi YQ, Wu KC, Zhang DX, Yang JH, Fan DM. Angiostatin up-regulation in gastric cancer cell SGC7901 inhibits tumorigenesis in nude mice. World J Gastroenterol 9: 59-64 (2003).

[148] O'Reilly MS, Boehm T, Shing Y, et al. Endostatin: an endogenous inhibitor of angiogenesis and tumor growth. Cell 88: 277-285 (1997).

[149] Zhang Q, Nie M, Sham J, et al. Effective gene-viral therapy for telomerase-positive cancers by selective replicative-competent adenovirus combining with endostatin gene. Cancer Res 64: 5390-5397 (2004).

[150] Forsythe JA, Jiang BH, Iyer NV, et al. Activation of vascular endothelial growth factor gene transcription by hypoxia-inducible factor 1. Mol Cell Biol 16: 4604-4613 (1996). 
[151] Semenza GL. Targeting HIF-1 for cancer therapy. Nat Rev Cancer 3: 721-732 (2003).

[152] Stoeltzing O, McCarty MF, Wey JS, et al. Role of hypoxia-inducible factor $1 \alpha$ in gastric cancer cell growth, angiogenesis, and vessel maturation. J Natl Cancer Inst 96: 946-956 (2004).

[153] Qiu RG, Chen J, Kirn D, McCormick F, Symons M. An essential role for Rac in Ras transformation. Nature 374: 457-459 (1995).

[154] Zhuge Y, Xu J. Rac1 mediates type I collagen-dependent MMP-2 activation. Role in cell invasion across collagen barrier. J Biol Chem 276: 16248-16256 (2001).

[155] Cascone I, Giraudo E, Caccavari F, et al. Temporal and spatial modulation of Rho GTPases during in vitro formation of capillary vascular network. Adherens junctions and myosin light chain as targets of Rac1 and RhoA. J Biol Chem 278: 50702-50713 (2003).

[156] Xue Y, Bi F, Zhang X, et al. Inhibition of endothelial cell proliferation by targeting Rac1 GTPase with small interference RNA in tumor cells. Biochem Biophys Res Commun 320: $1309-1315$ (2004).

[157] Alavi A, Hood JD, Frausto R, Stupack DG, Cheresh, DA. Role of Raf in vascular protection from distinct apoptotic stimuli. Science 301: 94-96 (2003).

[158] Meng F, Ding J, Liu N, et al. Inhibition of gastric cancer angiogenesis by vector-based RNA interference for Raf-1. Cancer Biol Ther 4: 113-117 (2005).

[159] Kim NW, Piatyszek MA, Prowse KR, et al. Specific association of human telomerase activity with immortal cells and cancer. Science 266: 2011-2015 (1994).

[160] Finkel T, Serrano M, Blasco MA. The common biology of cancer and ageing. Nature 448: 
767-774 (2007).

[161] Feng RH, Zhu ZG, Li JF, et al. Inhibition of human telomerase in MKN-45 cell line by antisense hTR expression vector induces cell apoptosis and growth arrest. World J Gastroenterol 8: 436-440 (2002).

[162] Ye J, Wu YL, Zhang S, et al. Inhibitory effect of human telomerase antisense oligodeoxyribonucleotides on the growth of gastric cancer cell lines in variant tumor pathological subtype. World J Gastroenterol 11: 2230-2237 (2005).

[163] Hendrick JP and Hartl FU. Molecular chaperone functions of heat-shock proteins. Annu Rev Biochem 62: 349-384 (1993).

[164] Hartl FU. Molecular chaperones in cellular protein folding. Nature 381: $571-579$ (1996).

[165] Sreedhar AS, Csermely P. Heat shock proteins in the regulation of apoptosis: new strategies in tumor therapy: a comprehensive review. Pharmacol Ther 101: 227-257 (2004).

[166] Sherman M, Gabai V, O'Callaghan C, Yaglom J. Molecular chaperones regulate p53 and suppress senescence programs. FEBS Lett 581: 3711-3715 (2007).

[167] Isomoto H, Oka M, Yano Y, et al. Expression of heat shock protein (Hsp) 70 and Hsp 40 in gastric cancer. Cancer Lett 198: 219-228 (2003).

[168] Zhao ZG, Shen WL. Heat shock protein 70 antisense oligonucleotide inhibits cell growth and induces apoptosis in human gastric cancer cell line SGC-7901. World J Gastroenterol 11: 73-78 (2005).

[169] Wallin RPA, Lundqvist A, Moré SH, von Bonin A, Kiessling R, Ljunggren HG. Heat-shock proteins as activators of the innate immune system. Trends Immunol 23: 130-135 (2002). 
[170] Radons J, Multhoff G. Immunostimulatory functions of membrane-bound and exported heat shock protein 70. Exerc Immunol Rev 11: 17-33 (2005).

[171] Nishikawa M, Takemoto S, Takakura Y. Heat shock protein derivatives for delivery of antigens to antigen presenting cells. Int J Pharm 354: 23-27 (2008).

[172] Kim R, Minami K, Nishimoto N, Toge T. Enhancement of antitumor effect by intratumoral administration of bax gene in combination with anticancer drugs in gastric cancer. Int $\mathrm{J}$ Oncol 18: 363-367 (2001).

[173] Takimoto R, Kato J, Terui T, et al. Augmentation of antitumor effects of p53 gene therapy by combination with HDAC inhibitor. Cancer Biol Ther 4: 421-428 (2005).

[174] Stevens C, La Thangue NB. A new role for E2F-1 in checkpoint control. Cell Cycle 2: 435-437 (2003).

[175] Bell LA, Ryan KM. Life and death decisions by E2F-1. Cell Death Differ 11: 137-142 (2004).

[176] Atienza C Jr, Elliott MJ, Dong YB, et al. Adenovirus-mediated E2F-1 gene transfer induces an apoptotic response in human gastric carcinoma cells that is enhanced by cyclin dependent kinase inhibitors. Int J Mol Med 6: 55-63 (2000).

[177] Namiki Y, Namiki T, Yoshida H, et al. Preclinical study of a "tailor-made" combination of NK4-expressing gene therapy and gefitinib (ZD1839, Iressa) for disseminated peritoneal scirrhous gastric cancer. Int J Cancer 118: 1545-1555 (2006).

[178] Min Y, Adachi Y, Yamamoto H, et al. Insulin-like growth factor I receptor blockade enhances chemotherapy and radiation responses and inhibits tumour growth in human gastric 
cancer xenografts. Gut 54: 591-600 (2005).

[179] Guo SY, Gu QL, Zhu ZG, Hong HQ, Lin, YZ. TK gene combined with mIL-2 and mGM-CSF genes in treatment of gastric cancer. World J Gastroenterol 9: 233-237 (2003).

[180] Zhang YM, Zhao YQ, Pan YL, et al. (2003) Effect of ZNRD1 gene antisense RNA on drug resistant gastric cancer cells. World J Gastroenterol 9: 894-898.

[181] Guo C, Ding J, Yao L, et al. Tumor suppressor gene Runx3 sensitizes gastric cancer cells to chemotherapeutic drugs by downregulating Bcl-2, MDR-1 and MRP-1. Int J Cancer 116: $155-160(2005)$

[182] Kirn D, Martuza RL, Zwiebel J. Replication-selective virotherapy for cancer: Biological principles, risk management and future directions. Nat Med 7: 781-787 (2001).

[183] Dalba C, Klatzmann D, Logg CR, Kasahara N. Beyond oncolytic virotherapy: replication-competent retrovirus vectors for selective and stable transduction of tumors. Curr Gene Ther 5: 655-667 (2005).

[184] Gridley DS, Slater JM. Combining gene therapy and radiation against cancer. Curr Gene Ther 4:231-248 (2004).

[185] Tarnawski A. Molecular mechanisms of ulcer healing. Drug News Perspect 13: 158-168 (2000).

[186] Tarnawski AS. Cellular and molecular mechanisms of gastrointestinal ulcer healing. Dig Dis Sci 50 Suppl 1: S24-33 (2005).

[187] Jones MK, Kawanaka H, Baatar D, et al. Gene therapy for gastric ulcers with single local injection of naked DNA encoding VEGF and angiopoietin-1. Gastroenterology 121: 
1040-1047 (2001).

[188] Chai J, Baatar D, Tarnawski, A. Serum response factor promotes re-epithelialization and muscular structure restoration during gastric ulcer healing. Gastroenterology 126: 1809-1818 (2004).

[189] Yang YH, Wu WKK, Tai EKK, et al. The cationic host defense peptide rCRAMP promotes gastric ulcer healing in rats. J Pharmacol Exp Ther 318: 547-554 (2006).

[190] Brandt S, Kwok T, Hartig R, König W, Backert S. NF-кB activation and potentiation of proinflammatory responses by the Helicobacter pylori CagA protein. Proc Natl Acad Sci USA 102: 9300-9305 (2005).

[191] Bhattacharyya A, Pathak S, Datta S, Chattopadhyay S, Basu J, Kundu M. Mitogen-activated protein kinases and nuclear factor- $\mathrm{kB}$ regulate Helicobacter pylori-mediated interleukin-8 release from macrophages. Biochem J 368: 121-129 (2002).

[192] Koch AE, Polverini PJ, Kunkel SL, et al. Interleukin-8 as a macrophage-derived mediator of angiogenesis. Science 258: 1798-1801 (1992).

[193] Kitadai Y, Sasaki A, Ito M, et al. Helicobacter pylori infection influences expression of genes related to angiogenesis and invasion in human gastric carcinoma cells. Biochem Biophys Res Commun 311: 809-814 (2003).

[194] Dirkx AEM, Oude Egbrink MGA, Wagstaff J, Griffioen AW. Monocyte/macrophage infiltration in tumors: modulators of angiogenesis. J Leukoc Biol 80: 1183-1196 (2006).

[195] Ishigami S, Natsugoe S, Tokuda K, et al. Tumor-associated macrophage (TAM) infiltration in gastric cancer. Anticancer Res 23: 4079-4083 (2003). 
[196] Kawakami S, Sato A, Nishikawa M, Yamashita F, Hashida M. Mannose receptor-mediated gene transfer into macrophages using novel mannosylated cationic liposomes. Gene Ther 7: 292-299 (2000).

[197] Koga M, Kai H, Egami K, et al. Mutant MCP-1 therapy inhibits tumor angiogenesis and growth of malignant melanoma in mice. Biochem Biophys Res Commun 365: 279-284 (2008). 
Table 1. Advantages and disadvantages of vector transfer routes for the stomach

\begin{tabular}{ccc}
\hline Routes & Advantages & Disadvantages \\
\hline \hline \multirow{2}{*}{ Systemic } & $\begin{array}{c}\text { Frequent dosing } \\
\text { Vast distribution }\end{array}$ & Non-specificity \\
\hline \multirow{2}{*}{ Direct injection } & Effective gene transfer \\
& High selectivity & $\begin{array}{c}\text { Physical force against organ } \\
\text { Limited region } \\
\text { Limited frequent dosing }\end{array}$ \\
\hline Intraperitoneal & Effective gene transfer & Low selectivity \\
\hline \multirow{2}{*}{ Serosal surface } & Effective gene transfer \\
High selectivity & Necessity of laparoscopy \\
\hline Oral & Easily administration & Barriers (epithelium, gastric fluid) \\
& Frequent dosing (daily intake) &
\end{tabular}


Table 2. Summary of strategies for gastric cancer treatment

\begin{tabular}{|c|c|c|c|c|}
\hline Categories & Genes (with drugs) & Vectors & In vitro/in vivo & References \\
\hline \multicolumn{5}{|c|}{ Suicide gene therapy } \\
\hline & HSVtk (GCV) & Adv & In vitro & {$[18]$} \\
\hline & HSVtk (GCV) & Adv & Intratumoral & [19] \\
\hline & $\mathrm{CD}(5-\mathrm{FC})$ & $A d v$ & i.p. & [20] \\
\hline \multicolumn{5}{|c|}{$\begin{array}{l}\text { Growth inhibition and } \\
\text { apoptosis induction }\end{array}$} \\
\hline & $\mathrm{p} 53$ & $\mathrm{CL}$ & In vitro & {$[59]$} \\
\hline & $\mathrm{p} 53$ & Adv & Intratumoral & {$[60]$} \\
\hline & p53 (HDAC inhibitor) & Adv & Intratumoral & {$[173]$} \\
\hline & $\mathrm{p} 51 \mathrm{~A}$ & $A d v$ & In vitro & {$[66]$} \\
\hline & Bax & Adv & Intratumoral, i.p. & {$[70]$} \\
\hline & $\begin{array}{l}\text { Bcl-2 antisense (CDDP, } \\
\text { PTX) }\end{array}$ & Naked & i.p. & [77] \\
\hline & Bcl-XL siRNA & $\mathrm{CL}$ & In vitro & [78] \\
\hline & RhoA siRNA or & $\mathrm{CL}$ & In vitro & [86] \\
\hline & DN RhoA & & & \\
\hline & RhoA and RhoC siRNA & Adv & In vitro & [87] \\
\hline & FasL & Adv & Intratumoral & [89] \\
\hline & Pro-caspase- 8 & Adv & i.p. & [93] \\
\hline & Rev-caspase-3 & $\mathrm{CL}$ & In vitro & {$[95]$} \\
\hline & Smad7 & $\mathrm{CL}$ & In vitro & [107] \\
\hline & PTEN & Adv & Intratumoral & [113] \\
\hline & Fhit & Adv, AAV & Oral & {$[116,117]$} \\
\hline & Puma & Adv & In vitro & {$[118]$} \\
\hline & $\begin{array}{l}\text { survivin antisense or } \\
\text { DN survivin }\end{array}$ & $\mathrm{CL}$ & Ex vivo & [122] \\
\hline & $\begin{array}{l}\text { E2F-1 (cyclin-dependent } \\
\text { kinase inhibitor) }\end{array}$ & $\mathrm{Adv}$ & In vitro & [176] \\
\hline \multicolumn{5}{|c|}{ Immunotherapy } \\
\hline & IL-2 & Retrovirus & Ex vivo & {$[125]$} \\
\hline & IL-10 & Adv & i.p. & {$[126]$} \\
\hline & MG7-Ag mimotope & Adv & Subcutaneous & {$[133]$} \\
\hline & ICAM-1 & $\mathrm{CL}$ & Ex vivo & {$[136,137]$} \\
\hline & ICAM-2 & Adv & Intratumoral & [139] \\
\hline \multicolumn{5}{|c|}{ Anti-angiogenesis } \\
\hline & sFlt-1 & Adv & i.p. & [39] \\
\hline & NK4 & Adv & Intratumoral & {$[145]$} \\
\hline & NK4 & Adv & i.p. & [40] \\
\hline & Endostatin & $A d v$ & Intratumoral & [149] \\
\hline & DN HIF- $1 \alpha$ & Stable line & Ex vivo & {$[152]$} \\
\hline & Rac1 siRNA & CL & In vitro & {$[156]$} \\
\hline
\end{tabular}


$\begin{array}{llll}\text { Raf-1 siRNA In vitro } \quad \text { CL } & \text { [158] }\end{array}$

Other strategies

$\begin{array}{llll}\text { iNOS } & \text { Retrovirus } & \text { In vitro } & {[15]} \\ \text { Teromelase antisense } & \text { CL } & \text { In vitro } & {[161]} \\ \text { HSP70 antisense } & \text { Naked } & \text { In vitro } & {[168]}\end{array}$

Abbreviations. Adv: Adenoviral vector; AAV: Adeno-associated viral vector; CL: Cationic liposomes; i.p.: intraperitoneal injection; CDDP: cisplatin; PTX: paclitaxel; DN: dominant-negative; iNOS: inducible nitric oxide synthase. 


\section{Figure legends}

Fig. (1). Section of the gastric wall and scheme of vector transfer routes.

Fig. (2). Pathways for apoptosis induction and inhibition. 
Fig. (1).

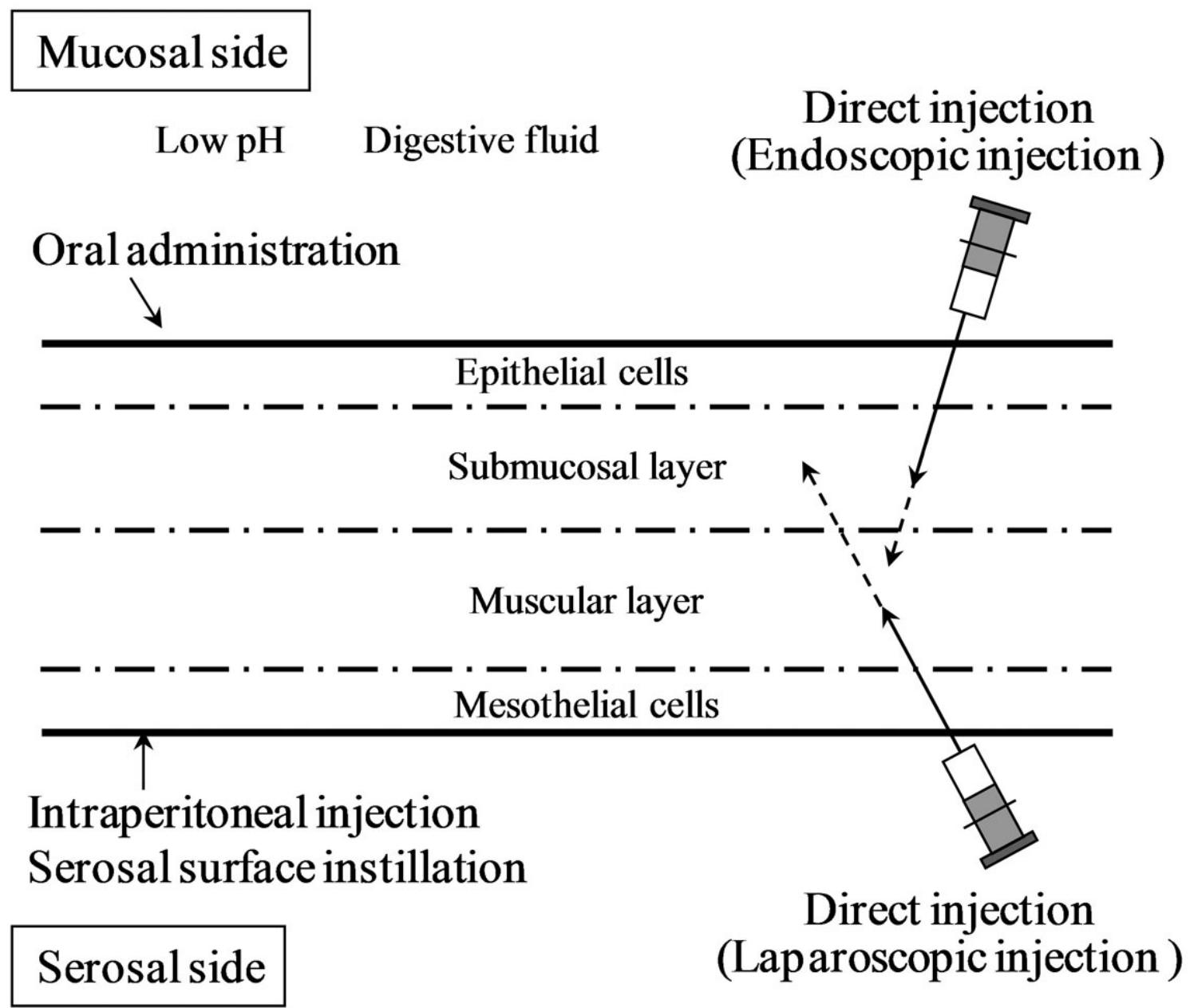


Fig. (2).

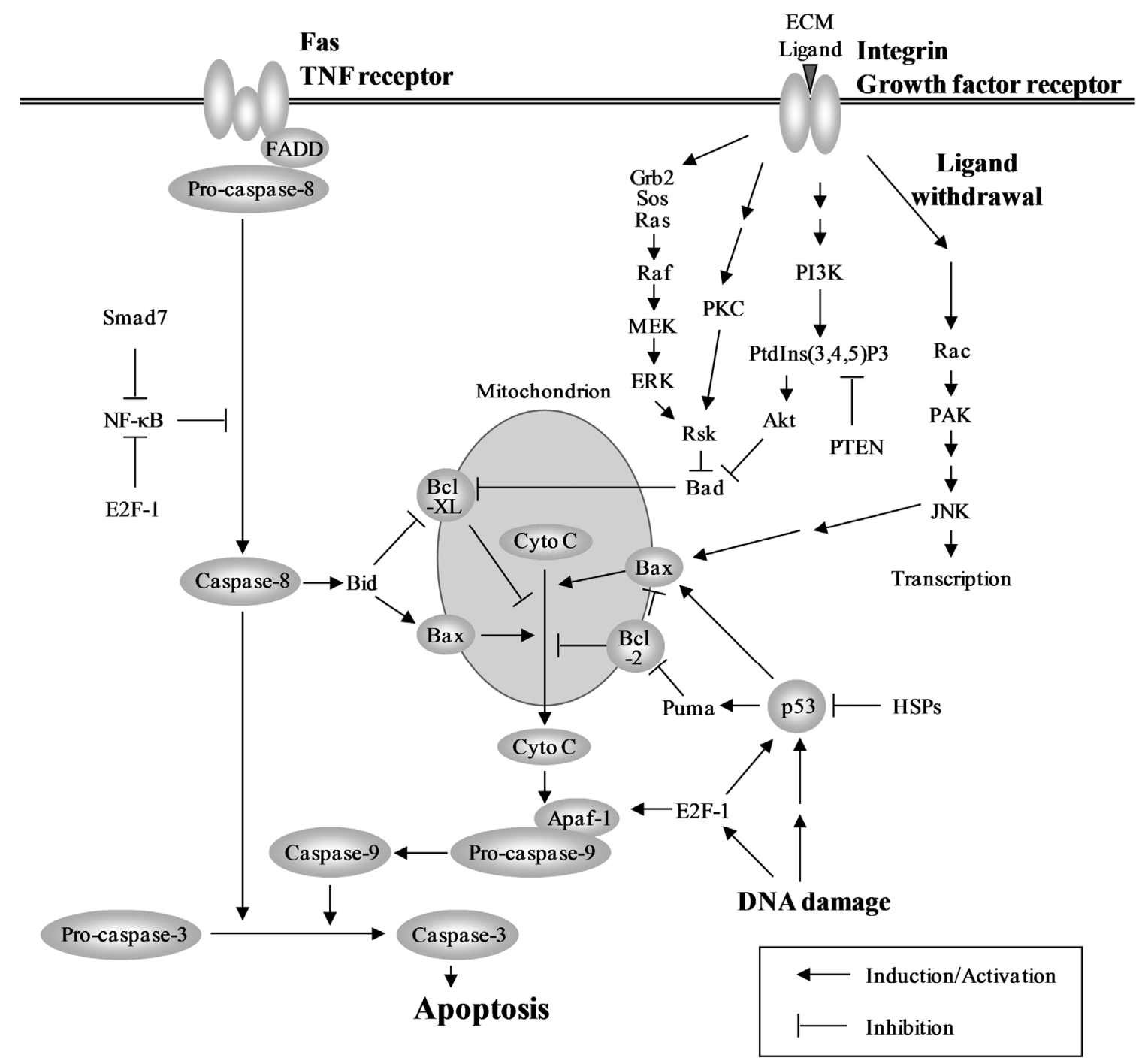

